\title{
OCCURRENCE OF THE NEW INVASIVE INSECT CYDALIMA PERSPECTALIS WALKER ON BOX TREE IN THE REPUBLIC OF MACEDONIA
}

\author{
Sterja Načeski ${ }^{1 *}$, Irena Papazova-Anakieva ${ }^{1}$, Blagoj Ivanov$^{1}$, Stanislava Lazarevska $^{2}$, \\ Blagoj Šurbevski ${ }^{1}$ \\ ${ }^{1}$ Faculty of Forestry, Ss. Cyril and Methodius University, Skopje, Republic of Macedonia \\ ${ }^{2}$ Faculty of Agricultural Sciences and Food, Ss. Cyril and Methodius University, \\ Skopje, Republic of Macedonia \\ "e-mail addres: snaceski@ sf.ukim.edu.mk
}

\begin{abstract}
The box tree pyralid Cydalima perspectalis (Walker 1859) is a new invasive moth species in Europe. Box tree moth was recorded for the first time in the Republic of Macedonia on box seedlings in parks, gardens and other urban green spaces in the city of Skopje in 2014. The aim of this study was to investigate the distribution and spread, the biology and lifecycle, as well as the damage caused by the different generations of the box tree moth in natural box tree stands, as well as in urban areas in R. Macedonia. In natural populations of Buxus, it was firstly recorded on the Vodno mountain in 2015. Since then, its population has a trend of progradation. Based on the results obtained, recommendations are given with measures for gradual regulation of the box tree moth populations. Standard entomological methods (monitoring of the phenomenon, population density and percentage of defoliation) were used.
\end{abstract}

Key words: Box tree moth; Cydalima perspectalis; box tree (Buxus); defoliator; abundance

\section{INTRODUCTION}

The box tree moth, Cydalima perspectalis [1] (Lepioptera: Pyraloidea: Crambidae: Spilomelinae) is native to East Asia, India [2]; China [1, 3]; Japan [4], Taiwan, Korea [5] and Eastern Russia [6].

In Europe it was introduced most probably with box seedlings [7]. It was first registered in $\mathrm{Eu}-$ rope in southwestern Germany in 2006 [8], while in 2007 it was found in Switzerland $[9,10]$ and Netherlands [11]. In 2008, box tree moth was found in Great Britain [12], France [13] and Austria [14]. In 2011 it appeared in Hungary [15], Romania and Turkey [16]. It was registered in Belgium [17] and Slovakia [18]. This invasive insect was found in Slovenia [19] and later in Denmark [20], while bioecological research on the development of $C$. perspectalis is provided by the authors: Maruyama [21], Maruyama \& Shinaji
[22-24], Székely et al [25], Tang et al. [26], Tominaga [27], Zhoo et al. [28].

In the Republic of Macedonia, $C$. perspectalis was recorded for the first time on box seedlings in parks, gardens and other urban green spaces in the city of Skopje, in 2014 (Novoselski Pat, 42 ${ }^{\circ} 01^{\prime} 09^{\prime \prime}$, $21^{\circ} 21^{\prime} 11^{\prime \prime}, \mathrm{K}-265 \mathrm{~m}$ [29].

The highest population of $C$. perspectalis was observed in urban environments, in Skopje (2014, 2015, 2016 and 2017) [30].

Buxus sempervirens L. is mostly present in the western parts of Republic of Macedonia, mainly Polog Valley along rivers of Treska and Pchinja, as well as in the Ohrid region. The easternmost part of the Buxus areal in the Republic of Macedonia is in the region of Demir Kapija at the foot of the mountain Serta, at altitudes from 100 to1000 m a.s.l, and along the edges of Boropole on the massif of Jakupica on 1600 m n.v. [31, 32]. 
In the newly invaded regions, $C$. perspectalis larvae feed on leaves of box trees, Buxus spp., resulting in defoliation, which can kill the trees $[3,5]$. The most significant damage, however, can be from the larvae attacking the bark of box trees causing the trees to dry out and die $[3,5]$. Besides cultural and economic effects, the most serious threat from $C$. perspectalis is on the natural Buxus populations.

The species can be easily introduced accidentally with its host plant, which is extensively traded throughout Europe and therefore presents a serious threat [33]. Climate models predict further spread of the species in Europe, invading most areas except for Northern Fenno-Scandinavia, Northern Scotland and high mountains [33].

Recently, this species has been found in the Balkan region (Croatia, Serbia, Bosnia and Herzegovina, Republic of Macedonia, Greece) [3437] and then in Bulgaria [38], Montenegro [36].

The significance of this research is in studying the invasiveness of the species, which from urban areas extends into the natural environment of the box populations. The aim of this study was to investigate the distribution and spread, the biology and lifecycle, as well as the damage caused by the different generations of the box tree moth in natural box tree stands, as well as in urban areas in R. Macedonia.

\section{MATERIALS AND RESEARCH METHODS}

For the realization of this research we have used standard and adapted methods for determining the abundance of Cydalima perspectalis, as well as the intensity of the attack and the degree of damage to leaves. These investigations were performed on stationary experimental plots, as well as at the entomological laboratory of the Faculty of Forestry in Skopje. The research was carried out from 2015 to August 2018. The methods consist of the following:

- The appearance and abundance of the box tree moth (Cydalima perspectalis) was monitored on experimental plots.

- Abundance is determined by the number of larvae found on 1000 leaves of box trees.

- The dynamics of emergence of butterflies and the dynamics of the number of its populations, as well as the development of the caterpillars, are observed on the experimental plots in Przino, Sredno Vodno and peak of Vodno.

-First and second-degree larvae were observed in the entomological laboratory at the Faculty of Forestry in Skopje. We followed the overall development of the box moth (Cydalima perspectalis): dynamics of emergence of butterflies; laying of eggs by females; larval development; the beginning of pupal stadium, i.e. the development of a whole generation [15].

- The intensity of the attack and the percentage of defoliation (damaged leaves) caused by feeding caterpillars were determined using a standard entomological method [15].

\section{RESEARCH RESULTS AND DISCUSSION}

C. perspectalis was recorded on natural Buxus populations for the first time on mountain Vodno in 2015. Since then, its population has a trend of progradation on Vodno. It has expanded almost everywhere, with incidents of defoliation observed in 2016 and 2017.

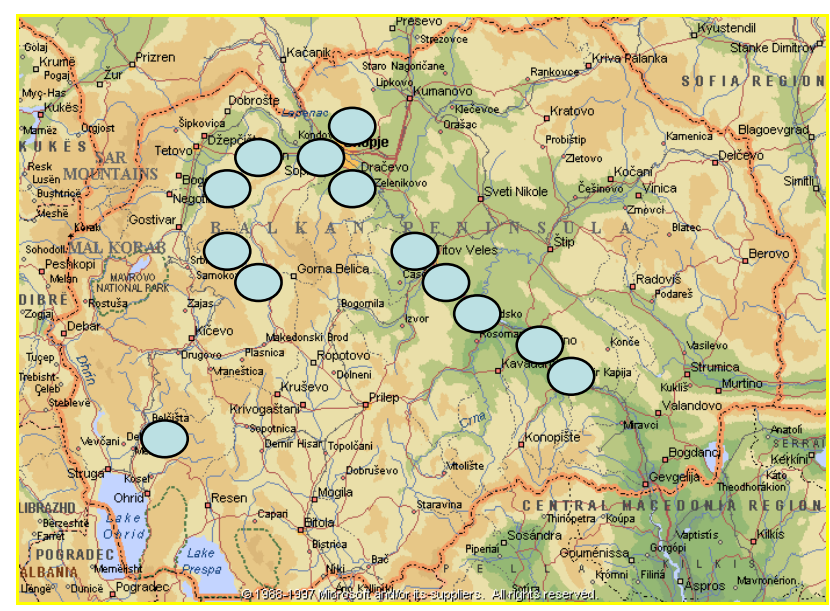

Figure 1. Natural sites of Buxus sempervirens in the Republic of Macedonia

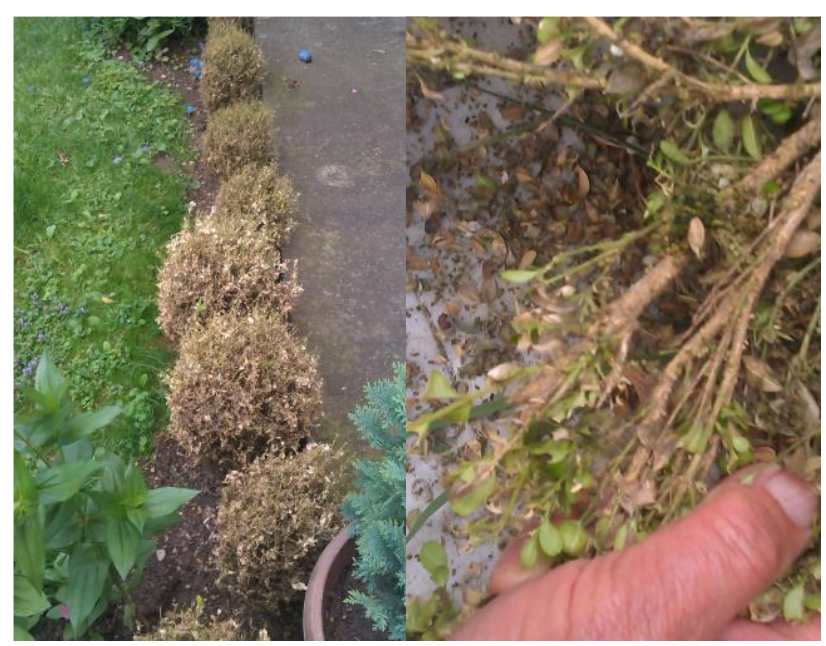

Figure 2. Defoliation caused by the caterpillars of the box tree moth near Skopje (Novoselski Pat). 
In the spring of 2017, we registered total defoliation on the site Sredno Vodno. The same year it was also registered in the natural Buxus populations on Matka. Box tree moth is not registered only on the top of Mt. Vodno, but due to its rapid spread it is expected that it will soon be present in this part of the mountain, where it appeared late in 2017.

Strong defoliations were recorded in July and August of 2018 at the base and the middle of Mt. Vodno. Particularly numerous were the second and third generation of box tree moth populations.

During its development the distinctly patterned larvae can reach several centimeters in length, and it is able to defoliate box tree shoots and totally destroy the whole bush or even hedges in public gardens, parks, cemeteries or home gardens. Due to the characteristic appearance of the pest and the damage caused (peeling and chewing of leaves, web and visible pieces of excrement on box tree shoots), the insect and the damage are not likely to be misinterpreted as other insect species or damage caused by diseases of box tree.

As the box tree moth may have several generations per year in Europe, and as the species is spreading not only by natural means but also with infested planting material via trade, its area of distribution and the levels of caused damage will probably grow rapidly in the coming years.

Table 1. Representation of $C$. perspectalis in Skopje areas

\begin{tabular}{|c|c|c|c|c|}
\hline Site & $\begin{array}{c}\text { Year } \\
\text { of appearance }\end{array}$ & $\begin{array}{c}\text { Area } \\
\text { under attack }\end{array}$ & $\begin{array}{l}\text { Intrensity } \\
\text { of attack }\end{array}$ & Defoliation \\
\hline & & per ha & & $\%$ \\
\hline 1. Skopje - urban area & 2014 & $+($ of all area $)$ & Very high & $75-100$ \\
\hline 2. Skopje - urban area & 2015 & $+($ of all area $)$ & Very high & $85-100$ \\
\hline Skopje - Vodno-natural area of box & 2015 & 100 & Moderate high & $30-85$ \\
\hline Skopje - Vodno -natural area of box & 2016 & 500 & Moderate & \\
\hline Skopje - Matka-natural area of box & - & - & very high & $55-90$ \\
\hline \multirow[b]{2}{*}{ Skopje - Matka-natural area of box } & 2017 & 1000 & Very high & $75-100$ \\
\hline & 2017 & 150 & Moderate very high & $25-80$ \\
\hline
\end{tabular}

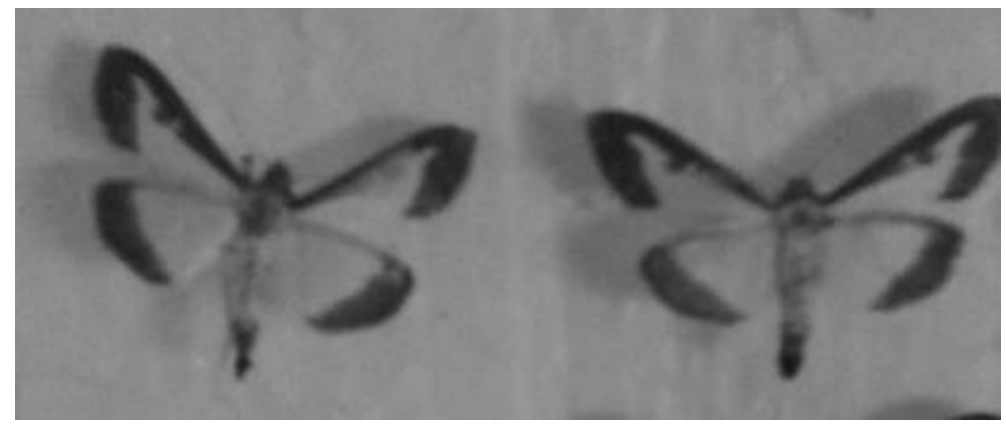

Figure 3. Adults of Cydalima perspectalis Walker (collected at the site of Sredno Vodno, 15.VIII 2015)

Table 2. Abundance of the Cydalima perspectalis populations in Skopje region

\begin{tabular}{lcccccccccccc}
\hline Year & & 2015 & \multicolumn{3}{c}{2016} & \multicolumn{2}{c}{2017} & \multicolumn{2}{c}{2018} \\
\hline Generation & I & II & III & I & II & III & I & II & III & I & II \\
\hline Locality & & & \multicolumn{8}{c}{ Number of caterpillars per 1000 leaves } \\
\hline Skopje-Przino & 22.3 & 74 & 89 & 38.1 & 89.4 & 105.3 & 32.7 & 49.2 & 100.5 & 17.6 & 56.8 \\
Sredno Vodno & 0 & 4.8 & 12.8 & 14.3 & 35.4 & 92.3 & 27.6 & 55.3 & 98.3 & 45.4 & 122.5 \\
Vrv Vodno & 0 & 0 & 0 & 0 & 0 & 0 & 0 & 1.2 & 2.4 & 12.5 & 41.7 \\
\hline
\end{tabular}




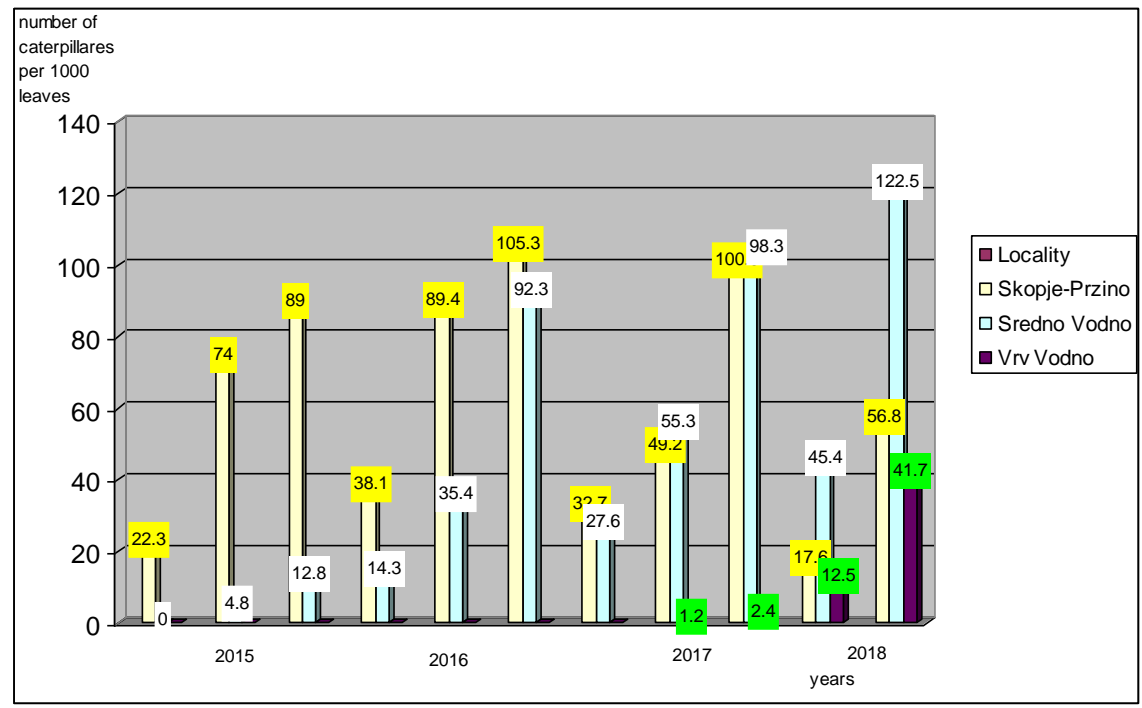

Figure 4. Abundance of Cydalima perspectalis populations in the Skopje region

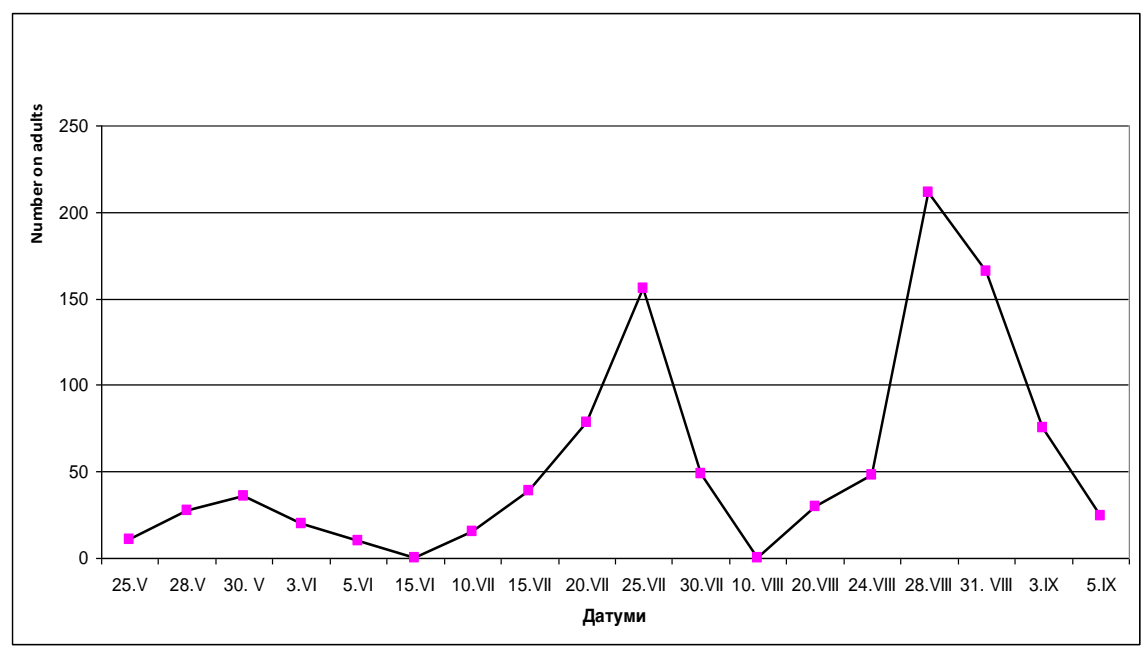

Figure 5. The dynamics of the appearance of butterflies of $C$. perspectalis, at the site of Vodno, Skopje in 2016

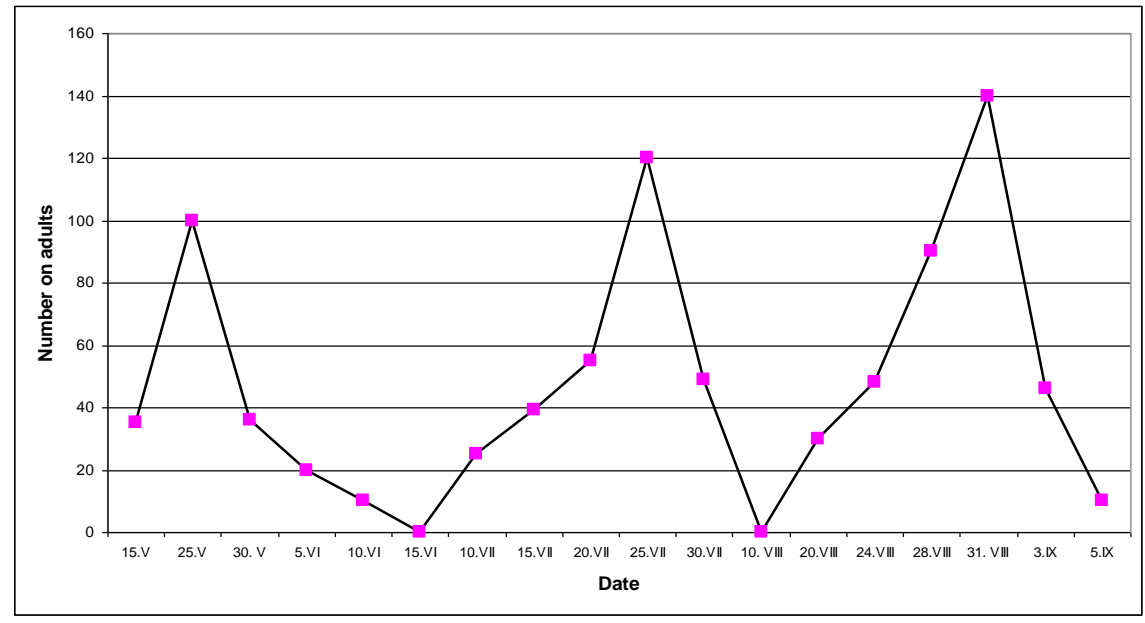

Figure 6. The dynamics of the appearance of butterflies of $C$. perspectalis, at the site of Vodno, Skopje in 2017 
During this research, three generations of Cydalima perspectalis were identified.

We are presenting the results of the dynamics of the abundance of $C$. perspectalis in Figure 4 and Table 2. It is most abundant at the site Pržino - in 2015 we registered 89 caterpillars on 1000 leaves of box; 105.3 in 2016 and 100.5 in 2017.

For the site of Sredno Vodno we registered gradation ranging from 12.8 in 2015, 92.3 in 2016, 98.3 in 2017 , to 122.5 in 2018 . At the site near the peak of Vodno, its abundance is the least of all, with an average of 2,4 caterpillars on 1000 leaves in 2017.

High populations of $C$. perspectalis are registered at the site of Matka and in the urban areas of Kavadarci, Ohrid, Prilep and other cities in the Republic of Macedonia in 2018.

\section{CONCLUSION}

Based on the field analysis and laboratory research we can give the following conclusions:

- Cydalima perspectalis, box tree moth was recorded for the first time in the Republic of Macedonia on box seedlings in parks, gardens and other urban green spaces in the city of Skopje in 2014.

- The most numerous populations of $C$. perspectalis were observed in urban environments, in Skopje (2014, 2015, 2016 and 2017), Kavadarci (2015, 2016, 2017) and Ohrid (2017).

- In the natural Buxus populations it was recorded for the first time on mountain Vodno in 2015. Since then, this population started to have a trend of progradation on Vodno. It has expanded almost everywhere, with evident defoliations in 2016 and in 2017. In the spring of 2017, total defoliation was detected on box trees at site Sredno Vodno.

- Box tree moth was registered at the peak of mountain Vodno at the end of 2017.

- It was also registered in the natural Buxus populations on Matka in 2017.

- It's most abundant at the site Przino - 89 caterpillars per 1000 leaves of box in 2015, 105,3 in 2016 and 100,5 in 2017; SrednoVodno- 12,8 in 2015, 92,3 in 2016, 98,3 in 2017 and 122,5 in 2018;

- At the site on the peak of Vodno, its abundance is the lowest of all, and is 2,4 caterpillars in 1000 leaves in 2017.

- The number of the first generation is the lowest in contrast to the second and third, when the number is multiplied.

- Strong defoliations were recorded at the base and the middle of the mountain Vodno, in July and August. Particularly numerous were the second and third generation of box tree moth populations.
- Accordingly, the population of the box tree moth varies from generation to generation over the years when the research was carried out.

- The number of the first generation is the lowest in contrast to the second and third, when the number is multiplied. The most numerous generation is the one that appears in the middle of the summer, i.e. August - September.

- Based on the results obtained, and especially due to the high population of $C$. perspectalis, recommendations should be given for the control of its populations for the regions of Vodno and Matka

\section{REFERENCES}

[1] F. Walker, List of the Specimens of Lepidopterous Insects in the Collection of the British Museum. Part XVIII. Pyralidae, British Museum (Nat. Hist.) London, 1859, pp. 509-798.

[2] G. F. Hampson, The Fauna of British India, including Ceylon and Burma, Taylor \& Francis, London, XXVIII, 1896, pp. 594.

[3] Y. Choo, H. T. Kaya, S. M. Lee, T. O. Kim, J. B. Kim, Laboratory evalution of entomophathogenic nematodes, Steinernema carpocapse an Heterorhabditis bacteriophora against some forest insects pests, Kor., J. Appl. Entomol., 30 (1991), pp. 227232, (in Korean, English abstr.).

[4] H. Inoue, Pyralidae, Moths of Japan 1, 2, H. Inoue, S. Sugi, H. Kuroko, S. Moriuti, A. Kawabe (Eds), Kodansha, Tokyo, Japan, 1982, pp. 223-254, 307404 (vol. 1), pp. 36-48, 228, 296-314 (vol. 2).

[5] I. K. Park, Ecological characteristic of Glyphodes perspectalis, Kor. J. Appl. Entomol., 47 (2008) pp. 299-301.

[6] V. A. Krpichnikova, Pyralidae, Key to the Insects of Russian Far East, 5 (2) 2005, pp. 526-539, (in Russian).

[7] R. Mally, M. Nuss, Phylogeny and nomenclature of the box tree moth, Cydalima perspectalis (Walker, 1859) comb. n., which was recently introduced into Europe (Lepidoptera: Pyraloidea: Crambidae: Spilomelinae). European journal of Entomology 107 (3) (2010), pp. 393-400.

[8] E. O. Krüger, Glyphodes perspeclis (Walker, 1859)neu für ie Fauna Europas (Lepidoptra: Crambidae), Entomol. Z. 118 (2008), pp. 81-83.

[9] F. Käppeli, Der Buchsbaumzünler, Elitempo durh basler Gärten, G'pluse-die Gärtner-Fachzeitschrift, (20) (2008), pp. 33.

[10] C. R. Sigg, (Auch das noch: Ein neuer BuchsSchadling schlagt zu. Massive Schaden durch den Buchsbaumzunsler.), Der Gartenbau , 4 (2009), pp. 2-4.

[11] M. Muus. T. S. T., E. van Haaften, J. van Deventer, L. J. van Deventer, De buxusmot Palpita per- 
spectalis (Walker) in Nederland (Lepidoptera: Crambidae), Entomol. Ber., 69 (2009), pp. 66-67.

[12] A. Mitchell, Box tree moth Diaphania perspectalis (Walk.) -a new pyralid moth to Britain and Ireland, Atropos, 36 (2009), pp. 17-18.

[13] J. F. Feldtrauer, J. J. Feldtrauer, C. Brua, Premiers signalements en France ela Pyrale u Buis iaphania perspectalis (Walker, 1859), espèce exotique envahissante s'ataquant aux (Lepidoptera, Crambidae), Bull. SocEntomol., 65 (2009) pp. 55-58.

[14] J. Rodeland. (ed.), Lepiforum, (2009) URL.; www. Lepiforum de.

[15] Sz. Sáfián, B. Horváth, Box Tree Moth - Cydalima perspectalis (Walker, 1859), new member in the Lepidoptera fauna of Hungary (Lepidoptera: Crambidae), Natura Somogyiensis, 19 (2011) pp. 245-246.

[16] E. Hizal, M. Kose, C. Yesiland, D. Kaynar, The New Pest Cydalima perspectalis (Walker, 1859) (Lepidoptera: Crambidae) in Turkey, Journal of Animal and Veterinary Advances, 11 (3) (2012), pp. 400-403.

[17] H. Casteels, J. Witters, S. Vandierendonck, L. van Remoortere, First report of Cydalima perspectalis (Lepidoptera: Crambidae) in Belgium, 63rd International Symposium on Crop Protection, Gent, Belgium, 2011, poster presentation.

[18] G. Pastorális, G. Elsner, F. Kopecek, F. Kosorin, A. Laštůvka, A. Lendela, J. Liška, J. Nimy, I. Richter, R. Stefanovie et al., Štrnást novÝch (2013).

[19] G. Seljak, Six new alien phytophagous insect species recorded in Slovenia in 2011, Acta Entomologica Slovenica, 20(1) (2012), pp. 31-44.

[20] D. Hobern-Cydalima perspectalis (Walker, 1859). https://www.flickr.com/photos/dhobern/941897008 3/ (2013). (accesed 8.08.2016)

[21] T. Maruyama, Life cycle of the box tree pyralid, Glyphodes perspectalis (Walker) (Lepidoptera: Pyralidae). IV. Effect of various host plants on larval growth and food utilization, Jap. J. Appl. Entomol. Zool., 37 (1993), pp. 117-122.

[22] T. Maruyama, N. Shinaji, Studies on the life cyle of the box tree pyralid, Glyphodes perspectalis (Walker) (Lepidoptera: Pyralidae). I. Seasonal adult emergence and developmental velocity, Jap. J. Appl. Entomol. Zool., 31 (1987), pp. 226-232.

[23] T. Maruyama, N. Shinaji, The life cyle of the box tree pyralid, Glyphodes perspectalis (Walker) (Lepidoptera: Pyralidae), II. Developmental characteristics of larvae diapause, Jap. J. Appl. Entomol. Zool., 35 (1991), pp. 221-230.

[24] T. Maruyama, N. Shinaji. The life cyle of the box tree pyralid, Glyphodes perspectalis (Walker) (Lepidoptera: Pyralidae). III. Potoperiodic induction of larval diapause, Jap. J. Appl. Entomol. Zool., 37 (1993), pp. 45-51.
[25] L. Székely, V. Dinca, C. Mihai, Cydalima perspectalis (Walker, 1859), a new species for the Romanian fauna (Lepidoptera: Crambidae: Spilomelinae), Buletin de Informare Entomologica, 22 (3-4) (2011), pp. 73-77.

[26] S. J. Tang, H. Z. Qin, W. Sun, Studies on bionomics of Diaphania perspectalis, J.Shanghai Agric. Collection, 8 (1990), pp. 307-312.

[27] S. Tominaga, Biological notes on Glyphodes perspectalis (Walker) an Herpetogramma basalis (Walker) (Pyraliae) in Okinawa, Yugato 154 (1998), pp. 119-120.

[28] W. Zhoo, C. Y. Xia, X. Q. Sun, B. Zhu, Z. P. Liu, Z. C. Liu, Y. Wang, Studies on the biological characteristics and control of Diaphania perspectalis Walker, J. Spanghai Jiotong Univ. Agric. Sci., 23 (2005), pp. 52-56.

[29] S. Nacheski, S. Lazarevska, I. Papazova-Anakieva, Cydalima perspectalis Walker (Lepidoptera, Crambidae) a new insect of Buxus sempervirens in the Republic of Macedonia, Plant protection journal, XXVII, (2015).

[30] S. Nacheski, I. Papazova-Anakieva, S. Lazarevska, Cydalima perspectalis new defoliator threat to natural population of boxwood in the Skopje region, Book of abstracts 70 years Faculty of Forestry-Skopje, (2017) pp. 27.

[31] H. Em, Review of the enroflorate of Macedonia, (spontaneous and suppositional VII), Union of Engineers and Forestry Technicians and Wood Processing Industry of the Republic of Macedonia, Skopje, 1967.

[32] S. Džekov, Dendrology, University Ss. Cyril and Methodius-Skopje, Skopje, 1988.

[33] S. Nacambo, F. L. G. Leuthardt, H. Wan, H. Li, T. Haye, B. Baur, R. M. Weiss, M. Kenis, Development characteristics of the box - tree moth Cydalima perspectalis and its potential distribution in $\mathrm{Eu}-$ rope, J. App. Entomol, Volume 138, Issue 1-2 (2013), pp. 14-26.

[34] T. Koren, M. Crne, The first record of the box tree moth, Cydalima perspectalis (Walker, 1859) (Lepidoptera, Crambidae) in Croatia. Natura Croatica, 21(2) (2012), pp. 507-510.

[35] D, Matosevic, Box tree moth (Cydalima perspectalis, Lepidoptera; Crambidae), new invasive insect pest in Croatia, SEEFOR, 4(2) (2013), pp. 89-94. http://www.seefor.eu/36-vol4-no2-matosevic.html

[36] I. Ostojic, M. Zovko, D. Petrovic, D. Elez, New records of box tree moth Cydalima perspectalis (Walker, 1859) in Bosnia and Herzegovina. (Novi nalazi simsirova moljca Cydalima perspectalis (Walker, 1859) u Bosni i Hercegovini.), Radovi Poljoprivrednog Fakulteta Univerziteta u Sarajevu (Works of the Faculty of Agriculture University of Sarajevo), 60(65(1)) (2015), pp. 139-143. 
[37] I. Strachinis, C. Kazilas, F. Karamaouna, N. Papanikolaou, G. Partsinevelos, P. Milonas, First record of Cydalima perspectalis (Walker, 1859) (Lepidoptera: Crambidae) in Greece, Hellenic Plant Protection Journal, 8(2) (2015), pp. 66-72.

[38] S. Beshkov, S. Abadjiev, D. Dimitrov, Cydalima perspectalis (Walker, 1859) (Lepidoptera: Pyraloidea: Crambidae: Spilomelinae). New invasive pest moth in Bulgaria. Entomologist's Record and Journal of Variation, 127 (2015), pp. 18-22.

[39] G. Pastorális, G. Elsner, F. Kopecek, F. Kosorin., A. Laštůvka., A. Lendela, J. Liška, J. Nimy, I. Richter, R. Stefanovie et al. Štrnást novÝch druhov motÝlov (Lepidoptera) pre faunu Slovenska, Folia Faunistica Slovaca, 18 (2013), pp. 1-12.

\title{
ПОЈАВА НА НОВ ИНВАЗИВЕН ИНСЕКТ СУDALIMA PERSPECTALIS WALKER НА ШИМШИРОТ ВО РЕПУБЛИКА МАКЕДОНИЈА
}

\author{
Стерја Начески ${ }^{1 *}$, Ирена Папазова-Анакиева ${ }^{1}$, Благој Иванов ${ }^{1}$, \\ Станислава Лазаревска ${ }^{2}$, Благој Шурбевски ${ }^{1}$ \\ ${ }^{1}$ Шумарски факултет, Универзитет „Св. Кирил и Методиј“, Скопје, Република Македонија \\ ${ }^{2}$ Факултет за земјоделски науки и храна, Универзитет „Св. Кирил и Методиј“, \\ Скопје, Република Македонија
}

Шимшировиот молец Cydalima perspectalis (Walker 1859) е нов инвазивен вид молец во Европа. C. perspectalis, беше за прв пат забележан во Р. Македонија на садници од шимшир во паркови, градини и други урбани зелени површини во градот Скопје во 2014 година. Целта на ова истражување беше да се определи распространувањето, биологијата и животниот циклус, како и оштетувањата предизвикани од различните генерации на шимшировиот молец во природните насади од шимшир, како и во урбаните подрачја во Република Македонија. Во природните насади од Buxus, за прв пат овој молец беше забележан на планината Водно во 2015 година. Од тогаш па наваму неговата популација таму има тренд на проградација. Врз основа на добиените резултати, и особено поради бројната популација на Cydalima perspectalis, се дадени препораки со мерки за постепено намалување на неговата популација на Водно. За ова истражување беа користени стандардни ентомолошки методи (набљудување на појавата, густината на популацијата и процентот на дефолијација).

Клучни зборови: Шимширов молец; Cydalima perspectalis; Шимшир (Buxus); дефолијатор; абунданца 
